\title{
POLITENESS PRINCIPLE: PRESIDENT JOKO WIDODO'S SPEECH ACT IN VIDEO BLOG
}

\author{
Risa Mufliharsi \\ Department of English Education Faculty of Language \& Art, \\ University of Indraprasta PGRI \\ risa.mufliharsi@unindra.ac.id \\ Heppy Atma Pratiwi \\ Department of Indonesian Language Education, Faculty of Language \& Art, \\ University of Indraprasta PGRI \\ heppyatma.pratiwi@unindra.ac.id
}

\begin{abstract}
The aim of the research is analyzing the utterances of Mr. Joko Widodo as president of Indonesia with vloggers. In this study, the writer analyzes the rules of president conducting his utterances at vloggers' vlogs. The vlogs taken from skinnyindonesian24 which has $1.3 \mathrm{M}$ subscribers and Arif Muhammad which has $1.5 \mathrm{M}$ subscribers (data per November 25,2018). The data taken and analyzed both qualitative and quantitative data. The elaboration of the methods used to measure language politeness, to count the data whether politenes or not. The data taken from Arif Muhammad's vlog (1.596.033 subscribers) which entitle Ngevlog bareng Presiden and SkinnyIndonesian24 were created by brothers Andovi da Lopez and Jovial da Lopez's vlogwho have 1.344.548 subscribers entitleHow to Become a President. The result of this research imply both of the vlogs Mr. Joko Widodo applies politeness strategies even in informal situation both vlogs. He acts extraordinary pragmatic forces and high politeness. So that, the audience gets the emotion, sympathy and persuasion of those who watches of them at vlog.
\end{abstract}

Keywords: politeness principal, speech acts, vlog, pragmatics

\section{INTRODUCTION}

There are many ways to communicate with others. One of them is conversation. Conversation is one of the most popular uses of human language (Liddicoat: 2007). It can deliver the message to otherform of idea, feeling, thought, and emotion easily. However, in daily conversation, this ideal communication does not always occur for some reasons. For politeness reason, for example, some people choose to break the rule of being informative as is required. Instead, they tend to give as much information they had. On other occasion, people due to their lack of investigation and knowledge may give wrong information to others. It also accurs that people sometime avoid being relevant in conversation since they asssume that their listener has already known what they mean or they deliberately choose to lie. The break up of the idea of mutual cooperation between interlocutor in communication may lead to what is called "implicature". Implicature in fact is the process when people fail to cooperate in their exchange. In this process, speakers imply something in their utterances which require the hearer to catch those implications by scrutinyzing

BAHTERA : Jurnal Pendidikan Bahasa dan Sastra, Volume Januari 2019 
the context of itution that elicits such utterances. Implicature is the assumptions behind the information. The logic and natural feeling can be assured to the audience or listener by using argumentation from the speaker without expressing it explicitely. Futhermore, implicature may mostly occur in a communication that involves in politics. The political utterances must adapt to the current context. In addition, most of the political utterances or political actions have many implied meanings. One of the political utterances that has implicature is applied in interview.

In interview, the politician may perform interestingly in front of the audience and the interviewer because he or she wants to catch the people's interest about what he or she talks. Moreover, if it is through the media, the speaker will act as well as possible in front of the audience and make his or her accepted.

Nowaday, everyone can make her or his news from his or her social media started from Friendster, Facebook, blog. Recently, people interest for using vlog. Vlog is short for video blog and usually pronounced "vlog". According to techterm.com, A vlog is a blog, or web $\log$, that includes video clips. It may be entirely video-based or may include both video and written commentary. So that people have ability to express themselves in a whole new way or people known as "vlogging". Other people can sit down in front of their video or web cameras and talk about anything, from politics to pop culture, upload their videos to YouTube and share their opinions with the world.

In Indonesia, the advancement in technology has allowed people to be widely known through social media, including YouTube. YouTube has provided a global platform for people to display their talent. There are few numbers of globally-known YouTubers due to their unique talents or videos. The fame and virality of YouTubers is calibrated by the number of subscribers and views.

One of Indonesian people who exists in YouTube is Mr. Joko Widodo whom people known as Indonesian President. As a president, Mr. Joko Widodo giving an impact to Indonesian including his speech act. It is important to be studied because being president should have intake Indonesian trust, interest, loyality and respected. In this research, the writer wants to find out the politeness of president's speech act in youtubers' vlog.

The objective of this research is to get comprehensively information related to the nature of president's speech act, specially in his politeness. Next, the result of study will be discussed in Pragmatics class as a material which is needed by students. Hopefully, being up to date in analyzing one's politeness involve students' creativity in interprate the linguistics.

The fokus of this research is to find out politeness of President's speech act in youtubers' vlogs, they are Arif Muhammad (1.596.033subscribers) which entitleNgevlog Bareng Presiden and SkinnyIndonesian24 were created by brothers Andovi da Lopez and Jovial da Lopez which have 1.344.548 subscribers entitle How to Become a President. In this research, the researcher see the strategy of president's language politeness in youtubers' vlogs, the cooperation principal in language politeness of president in youtubers' vlog, the function of the language politeness of president in youtubers' vlog, and the impact of language politeness of president in youtubers' vlog for audiences.

The questions that the researcher seen are:

1. What kinds of politeness happened in interview with Jokowi in SkinnyIndonesian24 vlog entitle How to Become a President and Ngevlog Bareng Presiden in Arif Muhammad's vlog? 
2. How do the politeness of speech act appear in interview with Jokowi in SkinnyIndonesian24 vlog entitle How to Become a Presidentand Ngevlog Bareng Presiden in Arif Muhammad's vlog?

\section{Pragmatics}

The advantage of using pragmatics while speak is people can say something to others without hurting their feelings by implicitly. People talk as their way to communicate with each other. In the communication, they do not always use a clear and explicit language. They modify how to deliver and change the content of what they talk to imply some intention. They intend to say something more specific with adding up another meaning in their utterances. This means that the meaning is more than just what the word said.

The study of pragmatics nowaday is not held in linguistics community only. Related to Hedayah and Kasemi's research (2018) in governmental offices. They got statistical society was one hundred person of the governmental clients. The results suggest that meanwhile the conversation, using face to face interactions and making utterance was satisfactory, but speech interruption was seen for 35 items, 12 items for keep client waiting, 21 items for ambiguous talking and paying enough attention to client's discourse was merely 38 items. Today the result of the study shows that the clients expect that their face to be preserved and the staff offices must implement the pragmatics strategies of politeness and face saving in format of positive and negative face in order to have a more effect on the clients.

Then, Samender's study (2016) which conducted pragmatics study relates to Economics. She identified there are two main factors in terms of economic data to be transmitted within the texts which are defined: a) the economic intratextual communicative interaction of the components of the act; b) components of the mutual relations between the texts found in the communicative act. Since the texts are the object of the linguistic study highlighted in terms of communication, the understanding of the texts of the text in the frame of extratextual economic factors has attracted the attention of researchers. In this case, the reader gets familiar with the text visually, through reading the text, through the impact of the economic mechanism, taking into account the pragmatic aspect of the components and the pragmatic realization of their characteristic. Next, She concluded that Two properties of expression of the textual modality are to be considered. First, the integrated function, i.e. integration of functional-semantic and stylistic categories in the text can be observed within economic texts. Secondly, the location of modal words in the narration is seen.Extra factors also play an important role in the realization of modal meanings of the economic texts. The main issue in the texts is the subject of conversation, verbal and visual data transmission, the language and methods of influence.

In social life, naturally people use pragmatics in daily interaction especially in social media. Scott (2017) analyzed hashtag online perform in a range of linguistic and pragmatic functions alongside their categorising and searching functionalities. (Scott, 2018). The findings showed that hastags are sometimes produced in spoken discourse, where the interlocutors share a physical context and are likely to have access to a range of contextual assumptions and non-verbal cues that are unavailable online. Data taken from attested spoken examples and show that spoken hashtags seem to be largely restricted to their interpersonal "metacomment" (Zappavigna, 2015, p. 6) function, and that they are most commonly used to provide evaluative judgements on the rest of the utterance and to guide 
inferences concerning the speaker's attitudinal stance. (Scott, 2018).

\section{Speech act}

According to Leech (1983), Speech act is 1) Showing people who asked with first speaker and assumtion of the speaker himself. 2) there are sentence of (sentenceinstance) or sentence token can be analyzed in pragmatics term. 3) communication is an effort to construct what next action that relates to speaker's purposes in producing the utterances. 4) It refers to product of action linguistics happened, 5) product of verbal action. The aspect of speech act. The aspect of speech act include speaker and listener, the purpose, speech act as linguistic action, and as a utterance product. (Leech, 19)

\section{Politeness}

At many utterances, both speaker and addresee build the meaning not only the signs, relationship between themeanings as seen at Semantics, but also interpreted the reference to the context, such as the settings, speakers, background the knowledge, and many things. In social interactions, there will be different ways to interpret the utterances. Basically, the conversation happened by the cooperation both speaker and addresee. Related to the cooperation happened, there will be sense which constructed by the conversation according to speaker and addresee. We can call it politeness.

Holmes (2013: 274) argued that norms of polite behaviour differ from one speech community to another. Liguistic politeness is culturally based. Different speech communities emphasise different functions, and express particular functions differently. So that, in real interaction, speaker and addresee may construct different politeness strategy. Related to
Leech in Chaer (2010) in Wibowo(2013), there are six politeness principals. They are tact (kebijaksanaan), generosity (penghargaan), approbation (penerimaan), modesty (rendah hati), aggreement (kecocokan), and symphaty (kesimpatian). Then, to identify kinds of politeness of speech act, there are scales to identify the politeness degree. They are: 1) Costbenefit scale, it's related to possitives and dis advantages of the utterance happened. 2) Optionality scale, it is related to how many choices in utterance which given by speaker to illocutor. 3) Indirectness scale, related to discourse happened. If all discourse occurin direct situation, it refers to impoliteness discourse. 4) Authority scale, it's related to the rank rating or relationship around the speaker and illocutor. 5) Social distance scale, it is related to social rating which occured in the discource.

Based on the descriptions above, it can be assumed that politeness show the cooperation of speaker and addressee and giving sense each other or maybe interpret others in possitive or negative politeness.

\section{Vlog}

A vlog (or video blog) is a blog that contains video content. The small, but growing, segment of the blogosphere devoted to vlogs is sometimes referred to as the vlogosphere. Some bloggers have included video content for years. However, vlogging is becoming more common as equipment becomes cheaper and supporting software and hosting and aggregation sites become more prevalent.

Kim (2017) indicated categories of vlog. The vlog categories include beauty, lifestyle, food, culture, travelling, motivation, cars, sports and education. Whereas television content does not provide users a selection of contents or schedule by individual preference, online platforms provide users freedom of content selection without time limitation. Video

BAHTERA : Jurnal Pendidikan Bahasa dan Sastra, Volume Januari 2019 
blogs provide informative, educational and entertaining sources and sometimes they create online communities amongst users with common interests and similarities. It seems that vlogs are not only about sharing one's own produced video contents but they connect diverse people with interests across the world. The vlog platform encourages users to build friendships and connections.

He also differenciated vlog and blog. A blog is a website on which a user regularly publishes their own posts including commentary, thoughts and ideas which contain photos, graphics, audio or video. Most blog sites are hosted by Tumblr, Blogger and WordPress. Blogs are used to provide news and content on a specific subject with personal interests. Visitors who read bloggers' articles share a specific article and comment on the article, which causes conversations between the author and readers. A vlog is a segment of blogosphere. Its primary messages are delivered by video contents, whereas blog contents mostly include texts with static images. General similarities of a blog and video blog are that they are user-generated contents. Many bloggers and vloggers with high popularity are supported by advertising or product sales. They prioritise the importance of interactions with other users who read and watch contents. From a brand perspective, the blog or vlog approach is a very effective marketing and branding technique. It is another direct way to present a brand's personality and an effective way for consumers to experience the brand and for the brand to interact with the consumers. Therefore, many famous fashion and food bloggers who started showcasing their work on their blog websites have transited to making vlog channels and many other users with other interests such as lifestyle, travelling and education have joined the vlogging trend and diversified the vlog communities.
In Indonesia, trend of vlog started by Youtube phenomena. Youtube became popular because everyone can access or upload his or her own video directly to others. The youtube itself categorize the term of video related to the genre of video itself. So, the audience can select which video wanted. Related to CNN Indonesia, vlog came up in 2015 because many nitizens upload their own video in Youtube. Then, people attended to audio visual content because people can be free to interpret the event, action, or maybe activity directly than writings as blog seen, or photos as instagram did.

According to Biel and GaticaPerez (2010b), conversational vlogs are a unique medium for self-presentation and interpersonal perception in social media, going beyond the use of text and still photos, which may partly explain the popularity of this format among online video users. However, despite the 35 hours of video uploaded per minute (and growing) reported by YouTube in their official blog (Nov. 2010), online video has received little attention from the social media community (Biel, et.al., 2011)

Related to the situation above, the writer interested to analyze the two vlogs from two channels that have same content. Both the channels showed the interactions between the vloggers and Indonesia's president, Mr. Joko Widodo. As a president, Mr. Joko Widodo giving an impact to Indonesian including his speech act. It is important to be studied because being president should have intake Indonesian trust, interest, loyality and respected.

\section{METHOD}

This method use descriptive qualitative and quantitative research. The elaboration of the methods used to measure language politeness, to count the data whether politenes or not. The data taken from Arif Muhammad's vlog (1.596.033 subscribers) which 
BAHTERA: Jurnal Pendidikan Bahasa dan Sastra, Volume 18 Nomor 1 Januari 2019 http://journal.unj.ac.id/unj/index.php/bahtera/

P-ISSN : 0853-2710

E-ISSN : 2540-8968

entitleNgevlog bareng Presiden and SkinnyIndonesian24 were created by brothers Andovi da Lopez and Jovial da Lopez's vlogwho have 1.344 .548 subscribers entitleHow to Become a President.

\section{BAHTERA}

JURNAL PENDIDIKAN BAHASA DAN SASTRA

The participants are the vloggers who interact with Mr. Joko Widodo. They used their own way to interact with the president. Both the vlog have different topic.

\section{a. Ngevlog bareng Presiden}
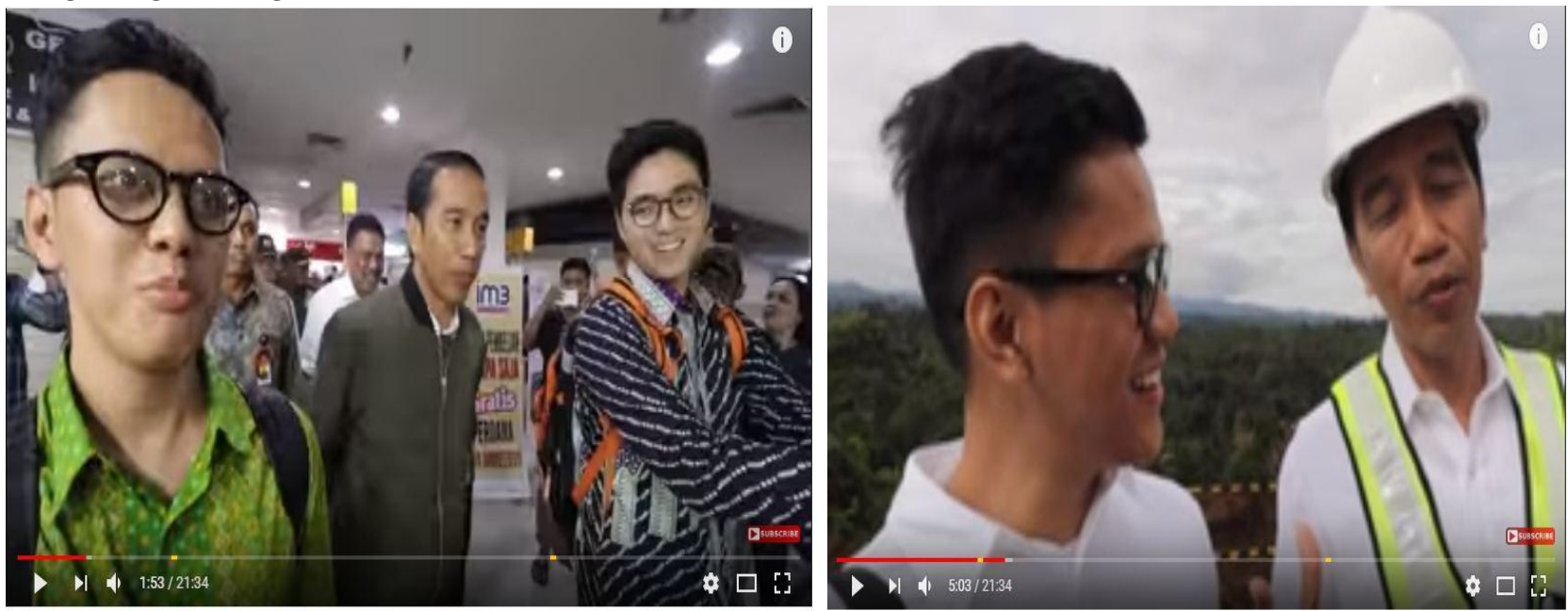

VLOGGG \#72: NGEVLOG BARENG PRESIDEN

This vlog told about Arif Muhammad's experience who had been invited to participate in president activities in Nusa Tenggara Barat. The conversation run naturally and informal outside presidential protocol. Besides, both of Arif as interviewer and Mr. Jolowi as interviewee cooperated during the events. They respected each other.

\section{b. How to Become a president at SkinnyIndonesian24}
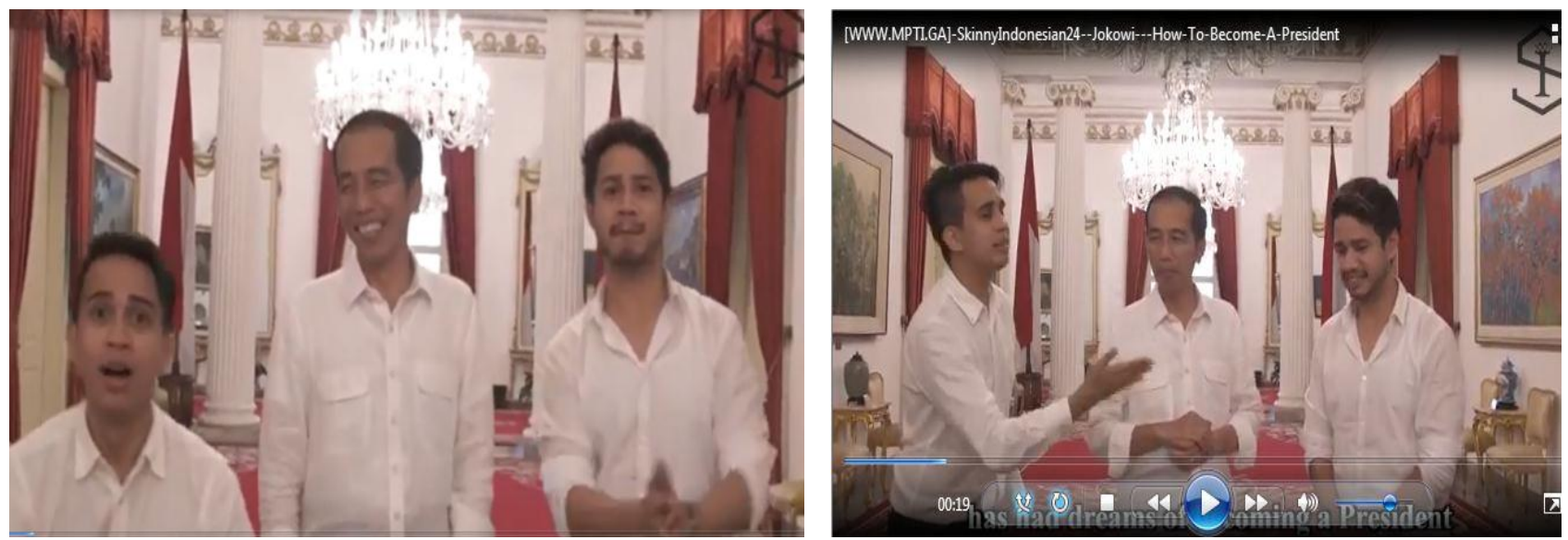

BAHTERA : Jurnal Pendidikan Bahasa dan Sastra, Volume Januari 2019 
This vlog told about Mr. Joko Widodo as a president gave some tips to Jovial da Lopez who wanted to be a president. The vlog's content was informal situation. Andovi who was an interviewer, sometimes interrupt Mr. Widodo explanation.

\section{Procedure of Research}

The steps are: 1) Collecting the data of the vlogs and describe them in transcript. There are two trancripts which taken from Ngevlog bareng Presiden of Arif Muhammad's vlog and How to Become a President of SkinnyIndonesian24's vlog. The method of collecting data using documentary and observasion. 2)The writer identified the data applied in

\section{RESULT AND DISCUSSION}

transcript. 3) In analyzing the data, the writer decide specification of politeness occured. 4)The units of utterances classified into clausa and sentence to decide the characteristics of verbal language used by president.5)Next, the writer checked the data by theory of triangulation and researcher of triangulation. Writer cited previous research entitle, Kajian Pragmatik Kesantunan Berbahasa Antara Najwa Shihab Dan Presiden Joko Widodo. It's written by Tri Wiratno et.al (Preceeding in International Seminar on Language Maintenance and Shift (LAMAS) 7, July 19-20 2017). There are four degrees to show the poliness occured, polite, rather polite, less polite, impolite

The writer analyzed the vlogs related to the six principals in politeness principals into two tables below:

Tabel 1 : skinnyindonesian24 entitle, How to Become a President run by Dovi and Jovi da Lopez

\begin{tabular}{|c|c|c|}
\hline $\begin{array}{l}\text { Politeness } \\
\text { Principals }\end{array}$ & Discourse & Total \\
\hline 1. Tact Principal & 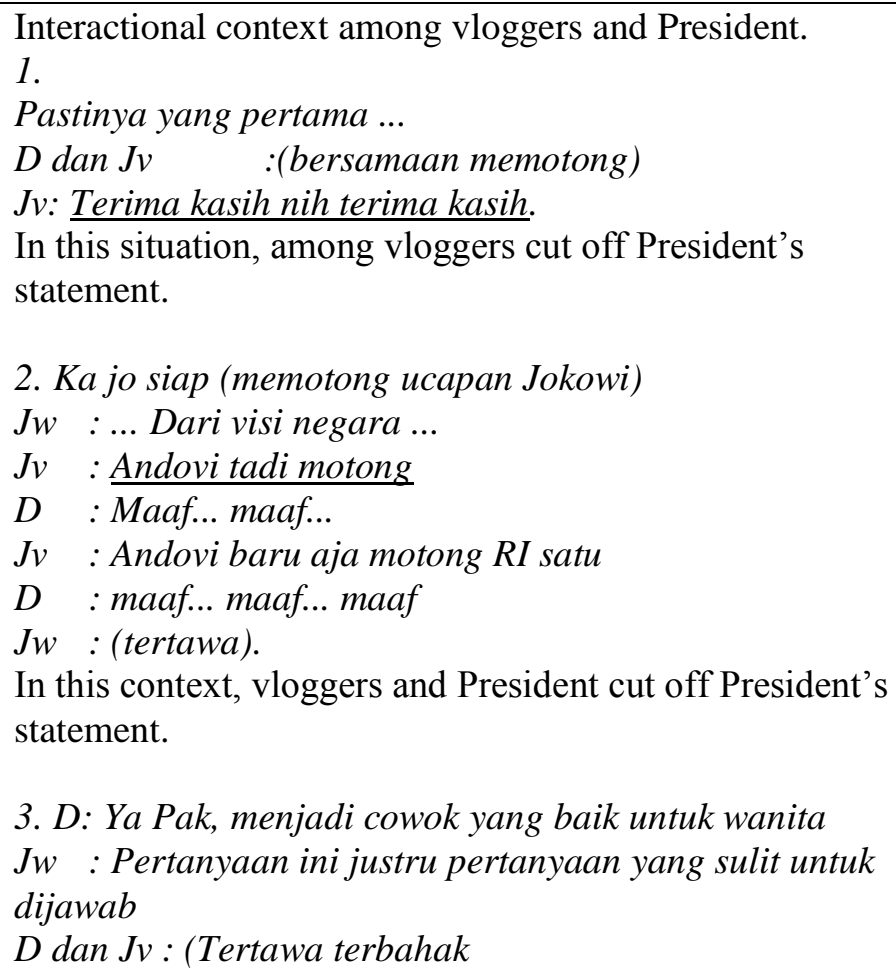 & $\begin{array}{l}3 \text { Broken } \\
\text { principals }\end{array}$ \\
\hline
\end{tabular}


BAHTERA: Jurnal Pendidikan Bahasa dan Sastra, Volume 18 Nomor 1 Januari 2019 http://journal.unj.ac.id/unj/index.php/bahtera/

P-ISSN : 0853-2710

E-ISSN : 2540-8968

\begin{tabular}{|c|c|c|}
\hline & $\begin{array}{l}\text { Jw : cukup sulit. } \\
\text { In this context, vloggers and President cut off President's } \\
\text { statement. }\end{array}$ & \\
\hline $\begin{array}{l}\text { 2. Generosity } \\
\text { Principal }\end{array}$ & $\begin{array}{l}1 . \\
D: \text { We are here with the president republic Indonesia } \\
\text { Jw : Halo halo halo (sambil melambaikan tangan } \\
\text { tertawa). } \\
\text { Vloggers introduced Mr. Jokowi as President of Indonesia. } \\
2 . \\
\text { Jv : and my name is Jovial da Lopez } \\
D \text { dan Jv: and this is ... } \\
J w: \text { Saya Jokowi } \\
\text { Vloggers give opportunity Mr. Jokowi to mention his name. }\end{array}$ & $\begin{array}{l}2 \text { principals } \\
\text { accepted }\end{array}$ \\
\hline 3. Modesty Principal & $\begin{array}{l}\text { D dan Jv: (bersamaan memotong) } \\
J v: \text { Terima kasih nih terima kasih } \\
D \quad \text { :Dengarkan ... } \\
J v \quad \text { : Dapet juga gue ... yoi (kepada Jokowi) } \\
\text { Vloggers show their thanking to Mr. Jokowi }\end{array}$ & $\begin{array}{l}1 \text { principal } \\
\text { accepted }\end{array}$ \\
\hline $\begin{array}{l}\text { 4. Approbiation } \\
\text { Principal }\end{array}$ & $\begin{array}{l}\text { 1. } \\
J w \quad \text { Pertanyaan ini justru pertanyaan yang sulit } \\
\quad \text { untuk dijawab } \\
D \text { dan Jv : Tertawa terbahak } \\
\text { At this context, the vloggers laughed at President's answer } \\
\text { related to the vloggers' question. } \\
2 . \\
J v \quad: \text { Andovi baru aja motong RI satu } \\
D \quad: \text { maaf... maaf... maaf } \\
J w \quad: \text { tertawa) } \\
D \quad: \text { jadi yang ketiga bekerja keras ya pak? } \\
J w \text { : ya, bekerja keras untuk mewujudkan misi negara } \\
\text { In this context, Mr. Jokowi didn't get angry with the } \\
\text { vlogger action who cut off his statement. He directly } \\
\text { laughed when the vlogger asked for appologizing. Then, he } \\
\text { still answered the vlogger's next question. }\end{array}$ & $\begin{array}{l}\text { Broken } \\
\text { principal and } \\
1 \text { accepted } \\
\text { principal }\end{array}$ \\
\hline $\begin{array}{l}5 . \\
\text { AggreementPrincipa }\end{array}$ & $\begin{array}{l}\text { 1. D : laksanakan? } \\
J v \quad \text { : laksanakan } \\
\text { In this context, Dovi didn't ask complete question to his } \\
\text { brother. Automatically, jovi replied it soon. } \\
\text { 2. Jv: Siap } \\
\text { (Jokowi dan Jovi bersalaman) } \\
\text { In this context, Jovi was ready to carry out the president's } \\
\text { tips by shaking each other. } \\
3 \quad \text { : Itu bagaimana Pak? Sya butuh tips Pak } \\
\text { Jv :Ya Pak, supaya ceweknya gak ninggalin dia Pak atau } \\
\text { gak ceweknya gak berpaling ke cowok lain } \\
D \quad: \text { Ya Pak, menjadi cowok yang baik untuk wanita }\end{array}$ & $\begin{array}{l}1 \text { broken } \\
\text { principal } \\
2 \text { accepted } \\
\text { principals }\end{array}$ \\
\hline
\end{tabular}

BAHTERA : Jurnal Pendidikan Bahasa dan Sastra, Volume Januari 2019 
BAHTERA: Jurnal Pendidikan Bahasa dan Sastra, Volume 18 Nomor 1 Januari 2019 http://journal.unj.ac.id/unj/index.php/bahtera/

P-ISSN : 0853-2710

E-ISSN : 2540-8968

\begin{tabular}{|c|c|c|}
\hline & $\begin{array}{l}\text { Jw : Pertanyaan ini justru pertanyaan yang sulit untuk } \\
\text { dijawab } \\
\text { In this context, President couldn't reply the vloggers } \\
\text { question, because he thought that was difficult for replied }\end{array}$ & \\
\hline $\begin{array}{l}\text { symphaty } \\
\text { (kesimpatian) }\end{array}$ & 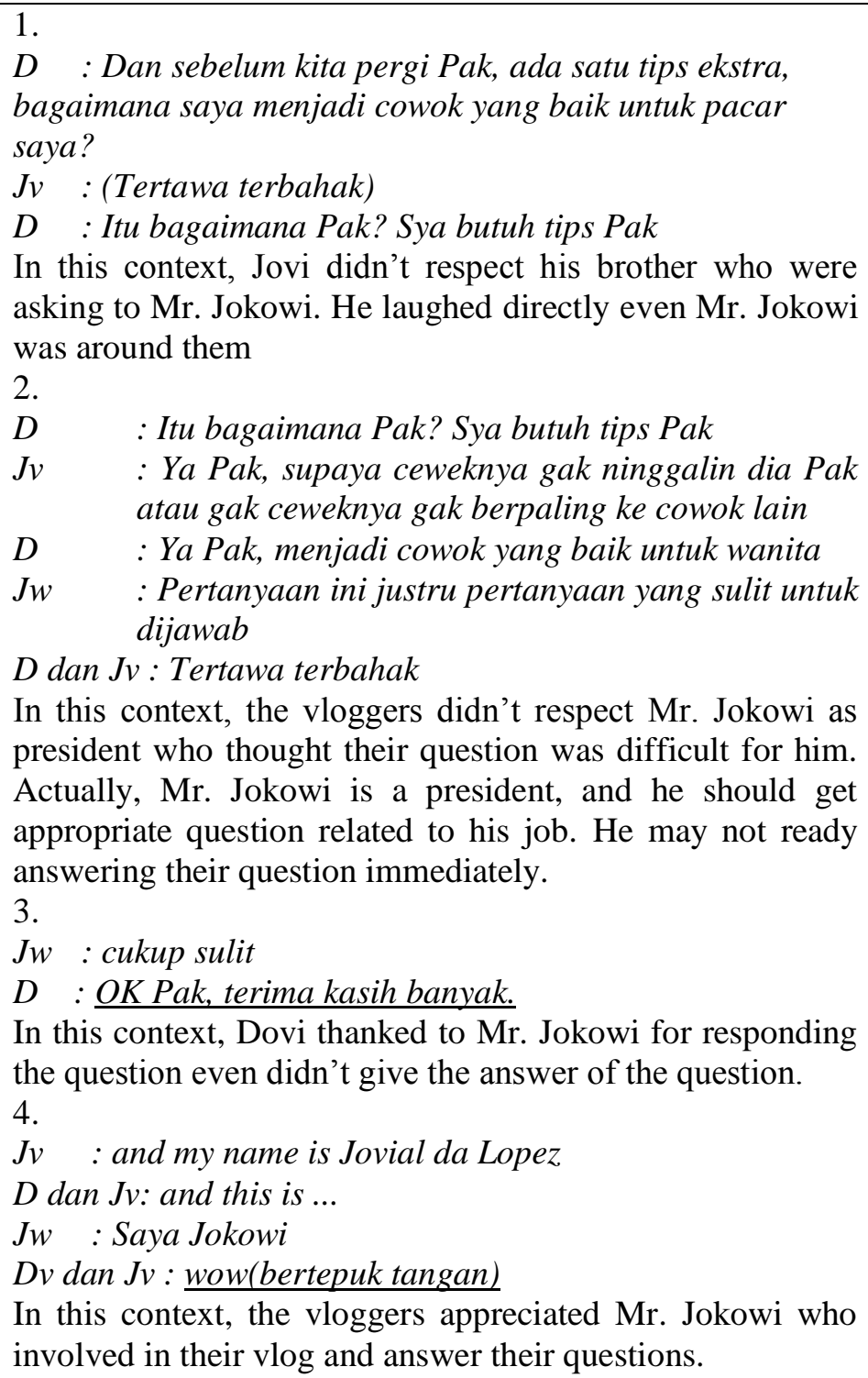 & $\begin{array}{l}2 \text { broken } \\
\text { principals } \\
2 \text { accepted } \\
\text { principals }\end{array}$ \\
\hline & Total & 15 \\
\hline
\end{tabular}

Tabel 2: Arif Muhammad, entitle "Ngevlog Bareng Presiden", run by Arif Muhammad

\begin{tabular}{|l|l|c|}
\hline $\begin{array}{c}\text { Politeness } \\
\text { Principals }\end{array}$ & \multicolumn{1}{|c|}{ Discourse } & Total \\
\hline 1. Tact Principal & $\begin{array}{l}\text { This vlog taken when Arif Muhammad invited to follow } \\
\text { Mr. Joko Widodo who is the president of Indonesia in his } \\
\text { official trip in the East of Indonesia. }\end{array}$ & $\begin{array}{l}\text { 3 accepted } \\
\text { principals }\end{array}$ \\
& $\begin{array}{l}\text { Fof AM : : Bapak ga capek, pak? } \\
\text { F (sambil tersenyum) }\end{array}$ & \\
\hline
\end{tabular}

BAHTERA : Jurnal Pendidikan Bahasa dan Sastra, Volume Januari 2019 
BAHTERA: Jurnal Pendidikan Bahasa dan Sastra, Volume 18 Nomor 1 Januari 2019 http://journal.unj.ac.id/unj/index.php/bahtera/

P-ISSN : 0853-2710

E-ISSN : 2540-8968

\begin{tabular}{|c|c|c|}
\hline & 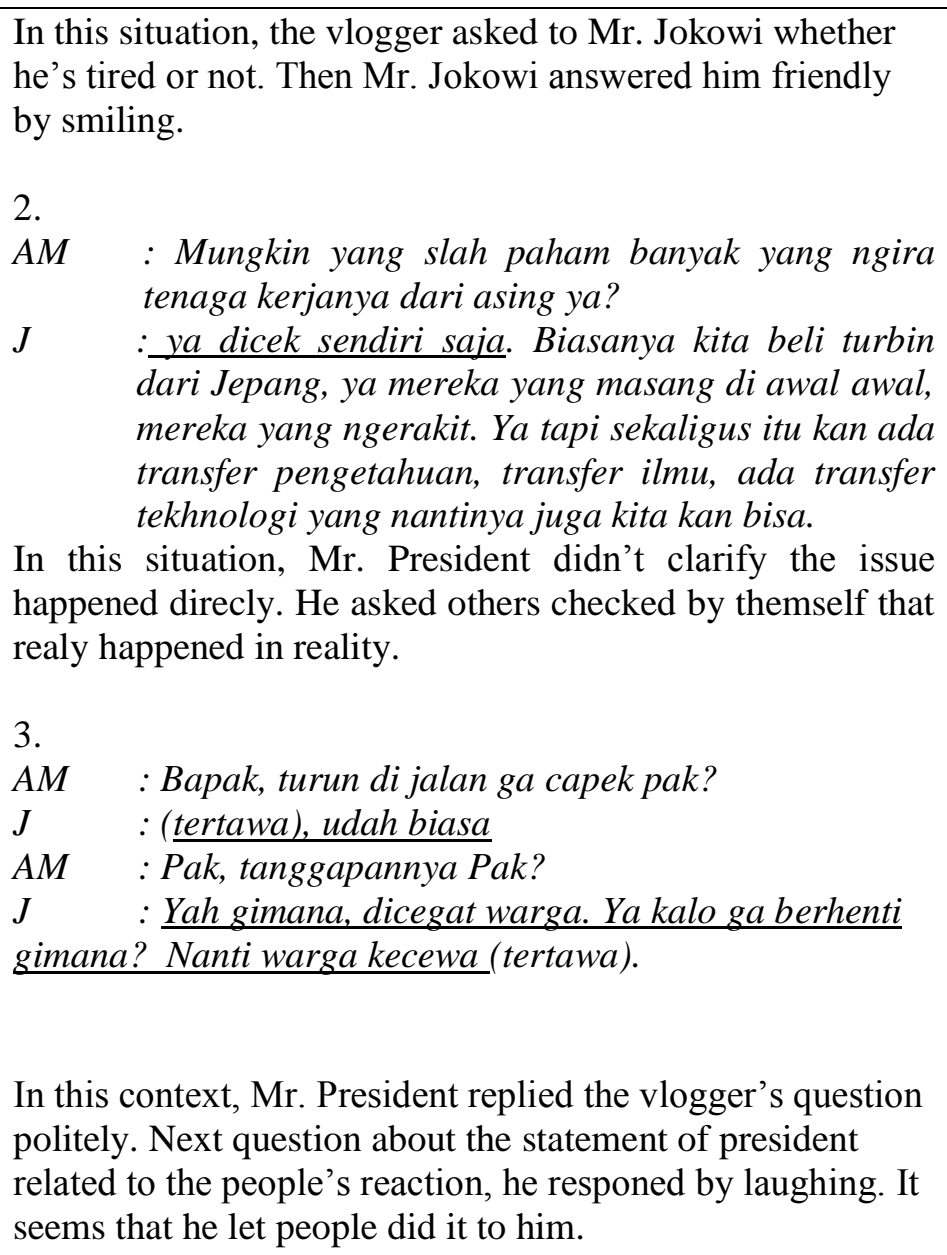 & \\
\hline $\begin{array}{l}\text { 2. Generosity } \\
\text { Principal }\end{array}$ & 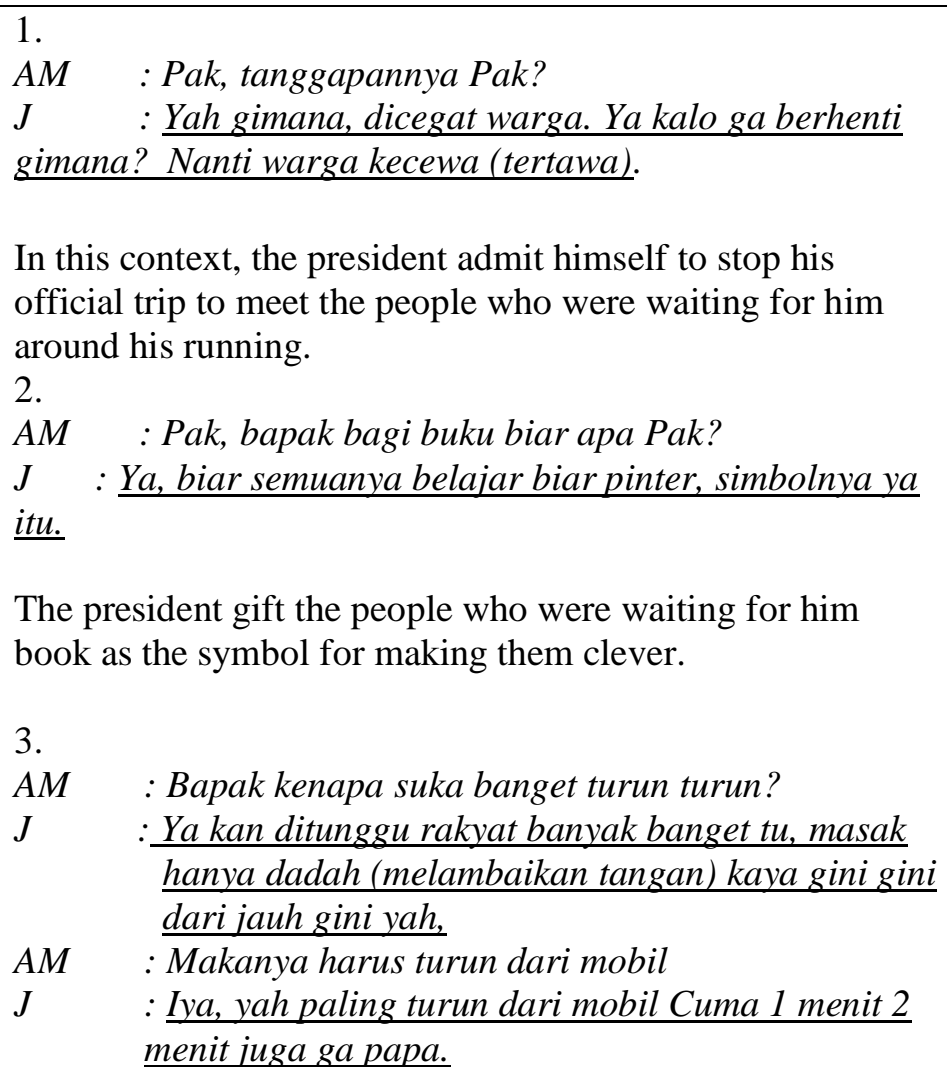 & $\begin{array}{l}3 \text { principals } \\
\text { accepted }\end{array}$ \\
\hline
\end{tabular}


BAHTERA: Jurnal Pendidikan Bahasa dan Sastra, Volume 18 Nomor 1 Januari 2019 http://journal.unj.ac.id/unj/index.php/bahtera/

P-ISSN : 0853-2710

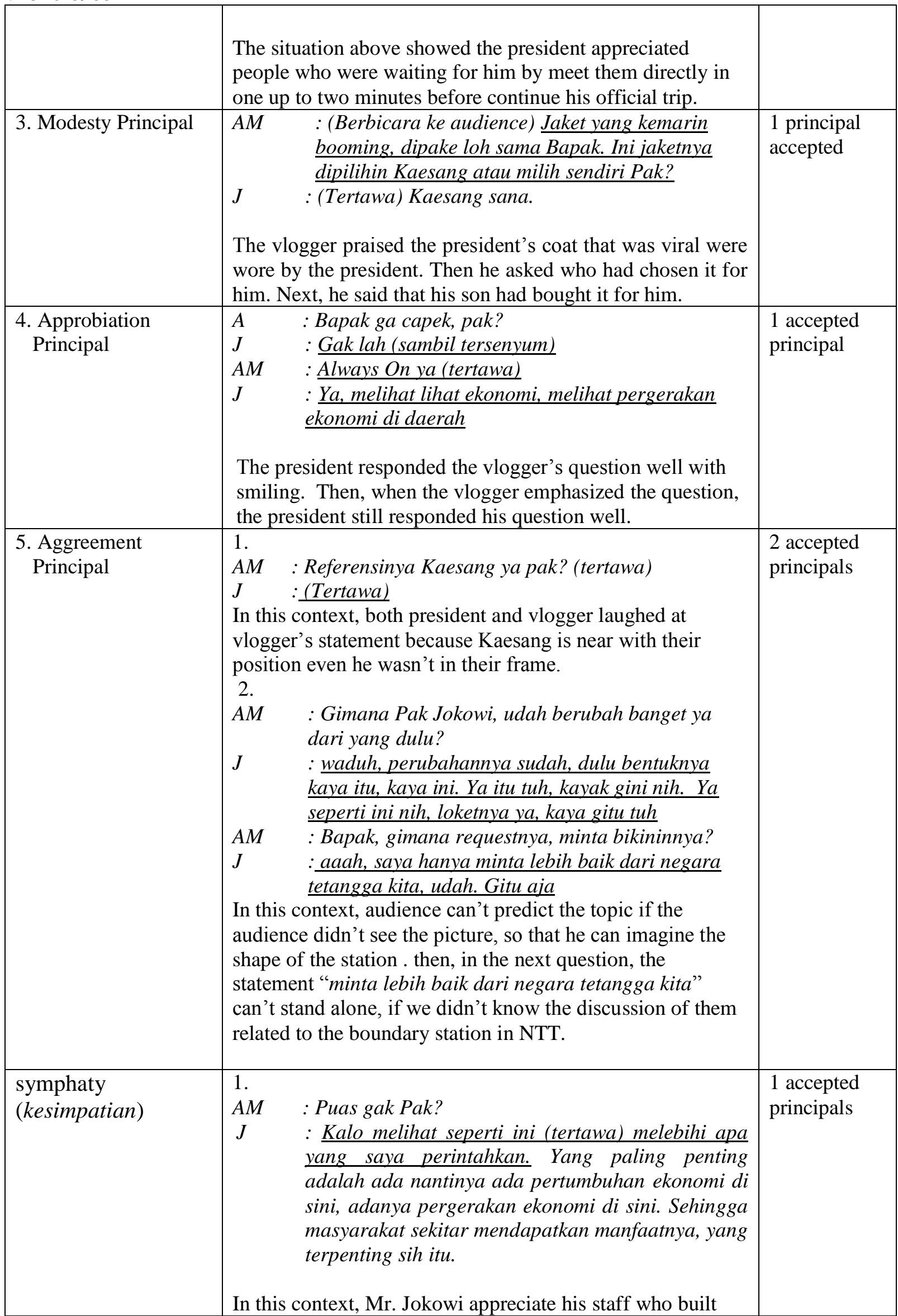




\begin{tabular}{|l|l|l|}
\hline & the boundary station because it is more than his expectation. & \\
\hline & Total & $\mathbf{1 1}$ \\
\hline
\end{tabular}

According to tables, on Skinnyindonesian24 vlog, there are many brokens principles occured. It may happen because their vlog's purpose is to amuse audience. So that they made concept finding another president' profile. So that, the discourse occured informal side. So that, this vlog will be unusual because related to President's job that tends to formal. Everybody in the world will see Mr.Jokowi is not the same with previous president did before. The interaction occured naturally and simply, only answering and responding the vloggers question. In politeness, the vlogis in rather polite, because they broke several principals of politeness.
Contrast, on Arif Muhammad's vlog, none broken principals occured. It may happen because he conducted his vlog during Mr. President's official trip. So that, his vlog told about president's real activities as president. Some of them maybe promote Mr. Joko Widodo as a good president who cares of his people, and also can be the way of campaign Mr. Joko Widodo's profile to others by clarifying the current issue that happened in Indonesia. In politeness, the vlogger is in polite, because none brokenprincipal of politeness occured even the discourse didn't occured in formal situation

Table 3: Broken Principals Data and Politess Status

\begin{tabular}{|l|l|l|l|}
\hline Vlog's Data & Broken Principals & Percentage & Politeness Status \\
\hline Skinnyindonesian24 & $\begin{array}{l}\text { - tact principle } \\
\text { - approbiation principle } \\
\text { - aggreement principle } \\
\text { - sympathy principle }\end{array}$ & $46,67 \%$ & Rather polite \\
\hline Arif Muhammad & - & $0 \%$ & Polite \\
\hline
\end{tabular}

\section{CONCLUSION}

Based on the findings and discussion, we can conclude that Mr. Joko Widodo showed politeness strategies in vlogs. In How to Become a President's vlog, Mr. Joko Widodo and vloggers did broken principals of politeness because the purpose of the vlog is to amuse the audience. The vloggers tended to do rather polite interaction even they knew that they were talking with president. The utterances that occured is natural and simple. The president only answered or responded the vloggers' question.

Besides, in Ngevlog Bareng Presiden's vlog, Mr. Joko Widodo and 
BAHTERA: Jurnal Pendidikan Bahasa dan Sastra, Volume 18 Nomor 1 Januari 2019 http://journal.unj.ac.id/unj/index.php/bahtera/

P-ISSN : 0853-2710

E-ISSN : 2540-8968

Arif Muhammad didn't brake politeness' principal because both of them cooperate and respect each other. Moreover, this vlog was conducted during Mr. President's official trip, so that it would be a facilitation for president informing his activities as a President of Indonesia to others. It indicates this vlog filled politeness among the speaker and addressee.

Related of the conclutions given, vlogs are trends in Indonesia should be performed politely. Whether the situation given is informal. It is caused by vlog will give impact to the audience or value to the audience. According to Mr. Joko Widodo did in both vlogs, the audience has different perception relates his interaction as president to vloggers. It caused by the politeness of the utterances can evoke the emotion,sympathy, and persuasion of those who listen to them.

\section{REFERENCES}

Biel, J. I., Aran, O., \& Gatica-Perez, D. (2011). You Are Known by How You Vlog: Personality Impressions and Nonverbal Behavior in YouTube. Proceedings of AAAI International Conference on

Weblogs and Social Media.

Barcelona: 2011. P.446

Hedayat, K., \& Kazemi, F. (2018). The Role of Politeness in the Employee-client Speech Interactions. Theory and Practice in Language Studies, 8(1), 100104.

Holmes, Janet. (2013). An Introduction to Sociolinguistics: Fourth Edition. Routledge: USA

Kim, Daeun. (2017). Vlog as a Branding Tool: How to Build a Brand with a Video Blog in Social Media. Thesis. Metropolia University of Applied Sciences Finland

Leech, G. N., \& Oka, M. D. D. (1993). Prinsip-prinsip pragmatik. Universitas Indonesia. Levinson, S. C. (1983). Pragmatics. England: Cambridge University Press

Maulana, Aqmal dan Hani Nur Fajrina. (2016). Dahulu ada blog, kini mulai ngevlog.https://www.cnnindonesia.co $\underline{\mathrm{m} / \text { teknologi/20160427183834- }}$ 185-127059/dahulu-ada-blogkini-mulai-nge-vlog diakses 15.57 $\underline{23 / 04 / 18}$

Muhammad, Arief. (2017, March 16). Ngevlog Bareng Presiden (Video

BAHTERA : Jurnal Pendidikan Bahasa dan Sastra, Volume Januari 2019 
BAHTERA: Jurnal Pendidikan Bahasa dan Sastra, Volume 18 Nomor 1 Januari 2019 http://journal.unj.ac.id/unj/index.php/bahtera/

P-ISSN : 0853-2710

E-ISSN : 2540-8968

file). $\quad$ Retrieved from

Sosiowati, I., \& Gede, G. A. (2013).

https://www.youtube.com/watch?

$\underline{\mathrm{v}=\mathrm{X} 5 \mathrm{ARgaS6fA0}}$

Nadar, F. X.(2009). Pragmatik dan Penelitian Pragmatik.

Yogyakarta: Graha Ilmu.

Nakrowi, Z. S. (2013). Implikatur Dan

Kesantunan Positif Tuturan

Jokowi Dalam Talkshow Mata

Najwa Dan Implementasinya

Sebagai Bahan Ajar Bahasa

Indonesia $\quad D i \quad S M K$ (Doctoral

dissertation, Universitas

Muhammadiyah Surakarta).

Samender, A. F. (2016). The communicative-pragmatic

classification of economic texts. Theory and Practice in Language Studies, 6(12), 2260.

SkinnyIndonesian24. (2016, August 10).

Cara Menjadi Presiden.(video

file). Retrieved from

https://www.youtube.com/watch?v

$=\mathrm{GV} 169$ nuivs

Kesantunan Bahasa Politisi dalam

Talk Show di Metro

TV. Disertasi. Denpasar:

Universitas Udayana.

Wibowo, S. E. (2013). Kesantunan Humor

Pejabat Dalam Wawancara:

Kajian Pragmatik. Proceeding of

Kesantunan Berbahasa dalam

Berbagai Perspektif, Magister

Pengkajian Bahasa Program

Pasca Sarjana universitas

Muhammadiyah Surakarta.

Surakarta: 1 Maret 2013. Hal.76-

77

Wiratno, Tri.et.al. (2017). Kajian

Pragmatik Kesantunan Berbahasa

Antara Najwa Shihab Dan

Presiden Joko Widodo.

Proceeding ofInternational

Seminar on Language

Maintenance and Shift (LAMAS)

7, Semarang: July 19-20 2017.

Hal.720 